\title{
PROBLEMS OF QUALIMETRY OF GIFTEDNESS
}

\author{
Alexandr Burov \\ Institute of Gifted Child of Ukraine at the National Academy \\ of Pedagogical Sciences
}

\begin{abstract}
The article deals with the problems of the qualimetry of giftedness caused by the lack of a conventional definition of the term giftedness and its quantitative criteria. The method of calculation of child giftedness' level and the quantitative measure of its expression is offered. On the basis of the proposed technique, the difference between comprehensive and special giftedness is demonstrated. Proposals for realization of some trends of research in giftedness are provided with the aim of their comparison with the studies of various authors.

KEYWORDS: giftedness, qualimetry, assessment, children.
\end{abstract}

\begin{abstract}
Anotacija
Straipsnyje kalbama apie talentingumo įvertinimo problemą, kurią sukelia termino talentingumas ir jo išmatavimo kiekybinių kriterijų stoka. Autorius pristato vaiko talentingumo lygio ir kokybinès jo raiškos įvertinimo metodą. Pristatomos technikos atskleidžia skirtumą tarp specialiujų ir bendrujų vaiko gabumų. Šios problemos sprendimas pagrịstas įvairių autorių lyginamujų tyrimų studijomis.

PAGRINDINIAI ŽODŽIAI: talentingumas, kiekybiniai matavimai, ivertinimas, vaikai.
\end{abstract}

\section{Introduction}

In the child giftedness' domain, its assessment remains an open question worldwide, despite a number of more or less recognized approaches. The main reason for that is the absence of at least two components, or prerequisites, of assessment: firstly, of a clear and generally accepted definition of the object of assessment (different authors, and especially practicians, offer different understandings of giftedness); and secondly, of the assesment criteria.

The situation is a result of the fact that the analysis of publications worldwide demonstrates a great number of definitions of the concept of giftedness. Even in the countries where the definition exists at a national level (as, e.g., in the USA), it is of a recommendatory nature. As a consequence, in the USA, along with the conventional definition, other definitions are used that serve as a basis for the studies of individual (famous) researchers (e.g., Renzulli's definition, 1986).

A large number of definitions is a consequence of the fact that no general agreement exists on the research object (mental characteristics of an individual, their manifestation in time in the shape of formation at a definite moment of time or the grade of their realization, absolute objective values of certain indicators or relative ones, through their comparison with the reference group, etc.) and its subject (what precisely is assessed: innate or acquired giftedness, its level and pace 
as the development in time, the possibility of comparison with something else, a natural or social character of giftedness, success in the realization of the individual potential, etc.). As a result, no criteria of assessment have been developed, or, to be more precise, they do exist in some cases, however, they cannot be compared due to different research bases (the definition, the object, and the subject). The absence of the definite criteria of assessment result in different assessments of the percentage of gifted children both in different countries and even, according to different researchers, in the same country . Thus, e.g., in China, $3 \%$ of the children are considered to be gifted, in European countries, 3 to $5 \%$ on the average, in Ukraine, 5 to $8 \%$, in Russia, according to different authors, the number fluctuates between 4 and $37 \%$, while in Canada, it is $70 \%$. Quite a few researchers (including the author) believe that all the children (at least, those healthy physically and mentally) are born with a wide range of traits that later develop into abilities and giftedness, however, not every case of giftedness is actualized (up to the level of socially recognized realization.

Moreover, different authors consider different levels to be the quantitative threshold of giftedness: according to Termen, it is $1 \%$ of the children by the outcomes of measurements of their intellectual abilities, in China, it is $10 \%$ of the children, while Renzulli and his adherents believe it "significantly exceeds the average level". The differences are very significant: from $1 \%$ to an indefinite boundary.

In accordance with a generally accepted and used approach, gifted children, in comparison with their peers, are characterized by advantages in all the parameters of development, including concentration of attention, memory, the ability of abstract thinking, and the pace of cognitive processes (Sternberg, 2000; Leites, 2003), increased sensitivity to new situations, the ability to predict the future, etc. The said characteristics manifest themselves in the genesis of the personality formation (Maksimenko, 2006), while the basis of the nature of giftedness as an individual characteristic of a child is the level of activity of the sensory-perceptual processes (Moliako, 2008). However, children with individual abilities (musical, mathematical, and other), strongly expressed against the average development of others, are also referred to as gifted.

It is obvious that the studies of children with special abilities provide for evidence-based approach to the categorization of a group of children that do not fall into the average statistical standard. The development of an effective complex of diagnostic methods is a difficult problem: its solution calls for a systemic approach which shall result in the gaining of new perspectives in the field of research in the phenomenon of child giftedness (Babiev, 2008). 
From the practical viewpoint, the complexity and the absence of objective assessment of giftedness due to the absence of the formal criteria of assessment provide a significant problem. In such a case, the quality and accuracy of the child giftedness' assessment depend on the researcher's experience, therefore, the said procedure is not so much a science as an art, which makes impossible the dissemination of it as a conventional means among practitioners.

The aim of the present research is the development of proposals on the introduction of giftedness assessment criteria for further formalization and for use as instruments for practical purposes.

\section{Methodology}

In relation to components of the giftedness' formation, three groups of views have been currently formed, depending on the contribution of one or another factor:

- genetically predetermined $G$ (with different levels of the contribution of heredity to the overall level of giftedness);

- totality of psychological characteristics of a personality $\Psi$;

- result of the social-pedagogical impact P.

A simplified model of the formed giftedness can be expressed by the following formula:

$$
O=\varphi\left(\beta_{1} G+\beta_{2} \Psi+\beta_{3} P\right),
$$

in which $\beta_{1}$ stands for significant coefficients of the contribution of a respective factor, depending on the viewpoint of the author of the model.

Given the fact that all the components of the model are variable and are not universally accepted, it is clear that the criteria of giftedness in such a context also cannot be generally recognized, therefore, it is impossible to compare the outcomes obtained by different authors. As a result, a practical problem of the comparison of the levels of children's giftedness' arises (as well as the correctness of the use of the term a gifted child), and generally, the reasonableness of the use of the term.

With the aim of the transfer of those problems from the philosophical level of discussion to the methodological one and the provision of respective recommendations for practitioners (teachers, psychologists, and the general public at large), it is considered to be necessary (for a relatively short transitional period, e.g., of 3 years):

- to record the definition of giftedness in compliance with its primary meaning and to stop its use (substitution) with respect to other phenomena; 
- to reach agreement with regard to the object referred to by that term;

- to define the subject (or the classes of subjects) as the characteristic of the object described by that definition;

- to accept a reasonable methodologically grounded criterion for assigning a child to the group of the gifted;

- to work out a quantitative criterion (a group of criteria) for the definition of giftedness and to study its (their) relevance in the real world practice.

Giftedness as a phenomenon manifests itself in one or another field of activity, or in several of them simultaneously, in the form of success in that activity, i.e. the achievement of certain results that can be measured qualitatively (as a rule) or quantitatively (by the indicators of direct activity or by taking special diagnostic tests). In the latter case, a necessity arises to have the common data on the performance of that kind of activity by assessment of average indicators for all children, as well as a quantitative measure of its performance by a specific child.

Provided the kinds of activity that children master in the process of learning are depicted in the form of an axis of the emergence of the types of activity and their getting increasingly complex, with an interval scale of all those types, and the quantity values of the obtained measurements of the performance of each activity are depicted on another axis, the sum of the values of the obtained estimates may be considered as a measure of the overall degree of the child's giftedness $P$, i.e. $P=\Sigma p i$, where $i$ is the number of the assessed kind of activity (see Fig. 1).

Provided $p_{i}^{n}$ is accepted as an average value for a definite type of activity, then the conditions to be met by gifted child shall be:

$$
p_{i}>>p_{i}^{n} u P>P^{c} \text {. }
$$

In such a case, overall giftedness can be diagnosed, and provided the second condition is not satisfied, a child can be assumed to have a special giftedness.

A question arises: what does "significantly more" mean $\left(p_{i}>>p_{i}^{n}\right)$ ?

We propose to consider $p_{i}>p_{i}^{c}+2^{\sigma}{ }_{i}$, i.e. the criterion of giftedness is the excess of the values that are estimated as two sigma, which corresponds to the general research practice (Yu, Burov, Kamyshin, 2008). 


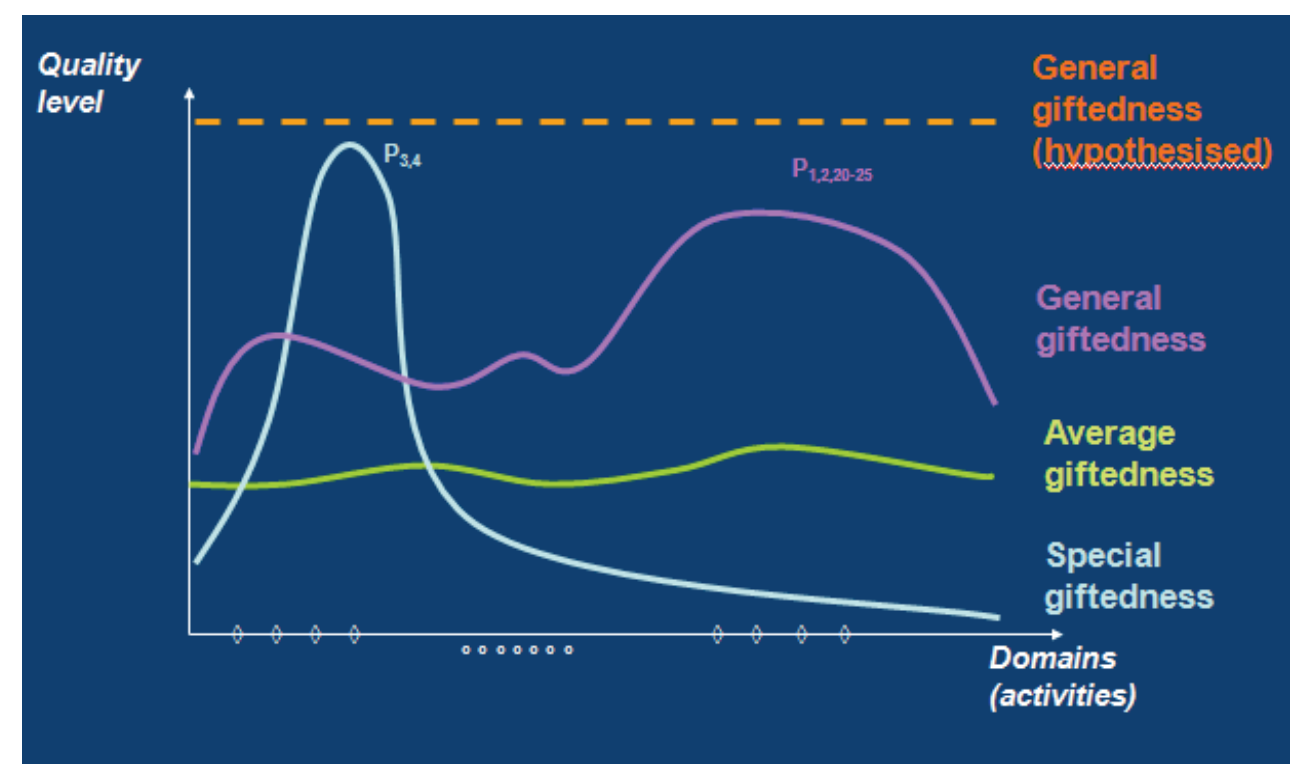

Fig. 1. Levels of giftedness depending on the kinds of the (learning) activity

Given the Flynn effect (the intelligence of each generation is supposed to be higher than that of the previous generation), the indicators of giftedness are to (hopefully) also go up, and with each generation of the children, $p_{i}^{c} \rightarrow p_{i}^{\max }$ is to be expected.

In research publications on the subject of gifted children, the comparison to other children or to an average level of learners is used as a criterion. However, whatever should be understood under "average values" has not been formalized. One has to admit that such a definition calls for specification which depends on the cohort of the respondents, i.e. the group in which the issue of the giftedness of one or another child is analyzed. The assessment should be done by taking into account at least the following groups:

- age group;

- ethnic (regional) group;

- gender group;

- $\quad$ professional group (of a specific institution, e.g., a mathematical school.

In other words, those simplified criteria can be used to obtain a quantitative measure of child's giftedness. Consequently, quantitative assessment is to be based 
on the creation and use of a database of assessment of the success of activity of a sufficiently large number of children of one or another age or professionally oriented (social, gender, etc.) group. In that case, the assessment of giftedness of a specific child or a group of children can be used for the personalization of their education and training.

\section{Results and proposals for the implementation of some trends of research in giftedness}

Trend 1.The nature of the word gifted in most existing languages means "what has been given from birth and was manifested in life", as opposed to what has been acquired in the process of life. It would be correct to add "in the case of development under standard conditions of a particular society". The comparison of children who were raised in different social conditions is not correct. To provide an example from history, the definition of IQ in the USA in the 50s highlighted an absolutely significant difference between the white and Afro-American populations, which afterwards was refuted due to the different levels of educational knowledge and skills in those groups.

The difference of such an understanding of giftedness from the "innate talents" is accounted for by the manifestation of the child's innate potential, and from the "abilities", by the absence of special development of the innate talents (as we know, the lack of development of the innate musical talent prevents us from talking about the ability, while, on the contrary, the training of an even modest innate talent leads to the manifestation of the child's "musicality" in comparison with most of others. For the description of the outcomes of realization, other terms are used: success, hard work, etc.

In the Russian and Ukrainian languages, two terms are used: a gifted child and a comprehensively gifted child. We are talking about two different levels of the manifestation of giftedness, but not about the giftedness as such

Consequently, the following definition of giftedness is proposed: a set of genetically and biorhythmically determined characteristics of a child that allow him/ her to achieve better results in comparison with other children of the same social group without any special development or training.

Trend 2. The object of the study of giftedness is a set of genetically and biorhythmologically determined characteristics of a child.

Trend 3. The subject that is defined by the indicated term is the manifestation of giftedness in a specific socially defined environment. The manifestation can be 
explored from different viewpoints: the achieved level, realization in time (at a specific moment), etc.

Trend 4. As a methodologically justified criterion, a standard sigma deviation from the mean (in one or more parameters) for the reference (social) group is proposed. Previously, we proposed the use of the upper 26, as the usual rule of the six sigma of the contemporary economics is too strong for people whose indicators are unstable over time and have a wide inter-individual variation. Even the rule of the top two sigma in a control group of 200 schoolchildren allowed to select only four of them, i.e. $2 \%$ with the use of social indicators.

The approach, just like any other, is arbitrary, however, it is more consistent with the current views of the use of quantitative statistical data.

Trend 5. Based on the above, the quantitative criterion of the assessment of giftedness alone can be considered not sufficiently realistic. Therefore, a more productive approach may be the development of a system of the criteria of giftedness which would allow a differentiated approach to the use of the criteria in practice. Thus, e.g., for a well-defined socially-predetermined group, it would be correct to use the "internal" criterion which is defined as 26 deviations from the mean value of an individual integral indicator or a certain system of tests for a school, a group of regional schools, or an educational level.

As external criteria, they may be definite levels of values of professionally significant indicators in one or another field of activity. Those may be, e.g., completion of a certain number (percentage) of mathematical problems of a particular type, a number of subjects in which a pupil achieved success in competitions or projects, or the level of achievements (prize winner in all-Ukrainian competitions, etc.).

Moreover, "external" criteria may include the level of achievements of child (including academic ones) in comparison with his own age group; the stability of success in the period of learning at school; a number of academic subjects in which the child surpasses 26 in his own school or in a reference group of schools, etc. The proposed criteria (a system of criteria) are subject for mandatory correction in accordance with the outcomes of the research in the total population within the boundaries of the Ukraine and in individual regions and types of educational institutions.

In other words, such simplified criteria may be used for obtaining a quantitative measure of child giftedness. As a result, quantitative assessment is to be based on the creation and use of a database on the assessment of successful performance of a sufficiently large number of children of one or another age group of profes- 
sionally oriented (social, gender, etc.) group. In such a case, the assessment of giftedness of a specific child or their group may be used for the personalization of their education or training.

Thus, e.g., in our research, the following methods of study of the schoolchildren at Kiev schools were applied by means of computerized methodology for assessing the intellectual giftedness of schoolchildren:

- the assessment of the intelligence structure by R. Amthauer: the assessment of abilities in the fields of arts and sciences;

- the Lüscher Colour Test (the method of paired selection): the assessment of the level of stress, the probability of social behavior, and the balance of psychological qualities;

- tests of assessment of the functional mobility of nervous processes: a modified Khilchenko-Makarenko method;

- Myers-Briggs types of inventory based on the ideas of C. G. Jung's typology;

- as a criterion of giftedness, normalized assessment of indicators is proposed to use. The most universal and easy to use is a scale built on the normalized assessments of all parameters.

If the normalization is in the range [0,1], the obtaining of assessment is associated with the degree of completeness of assessments received by a specific individual in relation to the maximum value ("standard"). That is particularly important given the fact that the quantitative and qualitative assessments by different methodologies of testing may be built on different scales, while the transition to the orthonormal scale allows to solve the problem of unification of the measured parameters (Figs. 2a and 2b).

Fig. 2. A fragment of a matrix of the "raw" (a) and normalized (b) assessment of the outcomes of a tested group of schoolchildren. 


\section{PROBLEMS OF QUALIMETRY OF GIFTEDNESS}

\begin{tabular}{|c|c|c|c|c|c|c|c|c|c|c|c|c|c|}
\hline 97 & $8-86$ & 10 & 7 & 1 & 6 & 7 & 11 & 12 & 11 & 29 & 36 & 65 & 95 \\
\hline 98 & $8-86$ & 11 & 9 & 8 & 2 & 6 & 8 & 9 & 10 & 38 & 25 & 63 & 92 \\
\hline 99 & $20-8 B$ & 12 & 6 & 7 & 7 & 6 & 5 & 0 & 12 & 37 & 18 & 55 & 80 \\
\hline 100 & $20-8 \mathrm{~B}$ & 10 & 5 & 13 & 11 & 11 & 11 & 7 & 11 & 39 & 40 & 79 & 116 \\
\hline 01 & $20-8 \mathrm{~B}$ & 10 & 5 & 13 & 11 & 11 & 11 & 7 & 11 & 39 & 40 & 79 & 116 \\
\hline 102 & $20-8 B$ & 14 & 4 & 8 & 8 & 10 & 12 & 8 & 18 & 44 & 38 & 82 & 120 \\
\hline 103 & Оболонь-8а & 4 & 4 & 2 & 2 & 2 & 11 & 6 & 5 & 15 & 21 & 36 & 53 \\
\hline 104 & $20-8 \mathrm{~B}$ & 5 & 9 & 3 & 10 & 7 & 6 & 4 & 16 & 33 & 27 & 60 & 88 \\
\hline 105 & Оболонь-8а & 10 & 9 & 13 & 16 & 16 & 13 & 12 & 14 & 46 & 57 & 103 & 151 \\
\hline 106 & $20-85$ & 13 & 8 & 10 & 9 & 15 & 10 & 16 & 14 & 45 & 50 & 95 & 139 \\
\hline 107 & Оболонь8а & 10 & 5 & 4 & 7 & 5 & 5 & 7 & 16 & 35 & 24 & 59 & 86 \\
\hline 108 & $20-8 a$ & 10 & 10 & 8 & 4 & 12 & 14 & 6 & 11 & 39 & 36 & 75 & 110 \\
\hline 109 & $20-8 \mathrm{~B}$ & 14 & 8 & 5 & 4 & 11 & 8 & 9 & 20 & 47 & 32 & 79 & 116 \\
\hline 110 & $20-8 a$ & 11 & 6 & 6 & 15 & 19 & 13 & 14 & 5 & 28 & 61 & 89 & 130 \\
\hline 111 & $20-8 \mathrm{~A}$ & 12 & 10 & 2 & 4 & 6 & 6 & 3 & 13 & 37 & 19 & 56 & 82 \\
\hline 112 & $20-8 a$ & 6 & 4 & 4 & 5 & 4 & 8 & 7 & 20 & 34 & 24 & 58 & 85 \\
\hline 113 & $20-8-A$ & 15 & 5 & 5 & 12 & 16 & 4 & 7 & 17 & 42 & 39 & 81 & 119 \\
\hline 114 & шк20, 8а клас & 11 & 8 & 5 & 10 & 14 & 7 & 9 & 10 & 34 & 40 & 74 & 108 \\
\hline 115 & $8-8 \mathrm{~A}$ & 11 & 8 & 8 & 1 & 5 & 7 & 6 & 2 & 29 & 19 & 48 & 70 \\
\hline 116 & $8-8 a$ & 5 & 6 & 3 & 2 & 2 & 8 & 3 & 5 & 19 & 15 & 34 & 50 \\
\hline 117 & $20-85$ & 6 & 9 & 3 & 4 & 5 & 16 & 6 & 5 & 23 & 31 & 54 & 79 \\
\hline 118 & $20-8-6$ & 8 & 4 & 3 & 3 & 2 & 8 & 11 & 5 & 20 & 24 & 44 & 64 \\
\hline 119 & оболонь-8а & 12 & 8 & 13 & 5 & 7 & 14 & 11 & 15 & 48 & 37 & 85 & 124 \\
\hline 120 & $8-8 a$ & 12 & 4 & 5 & 5 & 6 & 6 & 4 & 12 & 33 & 21 & 54 & 79 \\
\hline
\end{tabular}

(a)

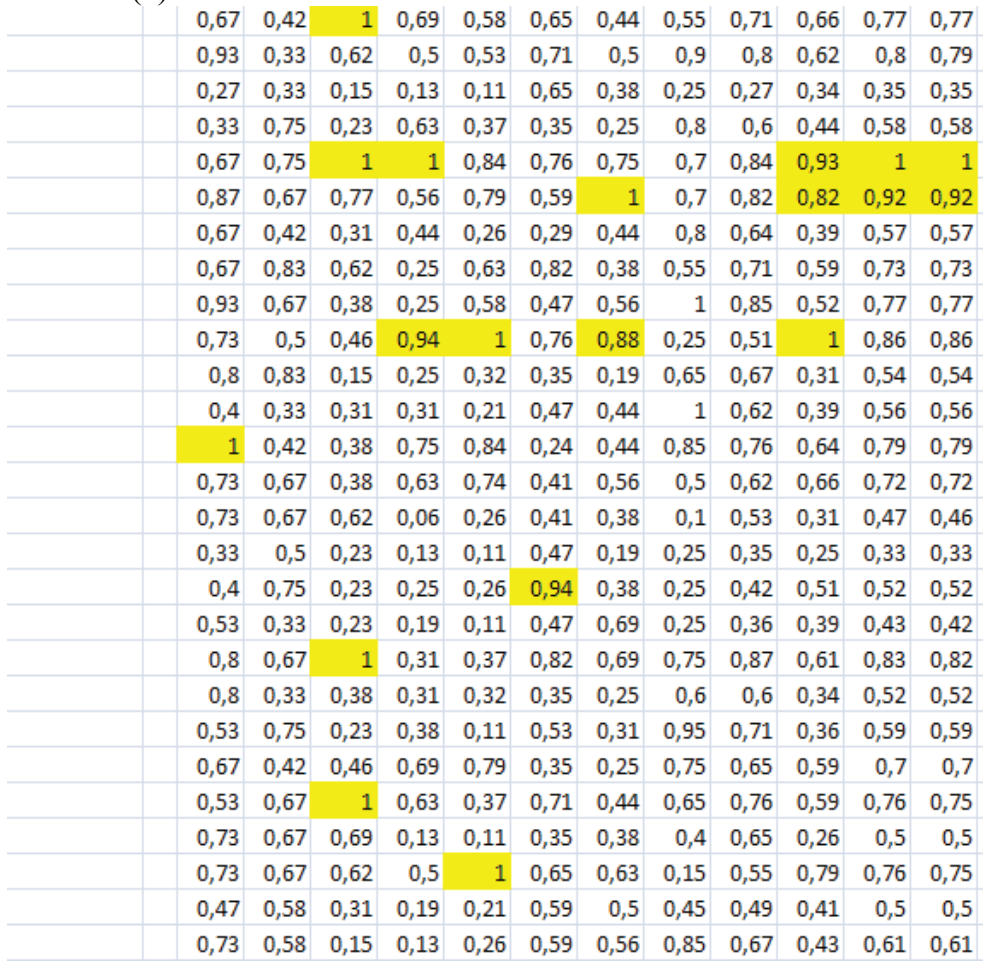

(b) 
Alexandr Burov

\section{Conclusions}

1. Assessment of giftedness should be systemic assessment of an individual's development.

2. Assessment of child's giftedness should be based on quantitative assessment of the development of an average level of psychophysiological, academic, social, and other indicators of a relevant group.

3. The level of child's giftedness may be quantitatively assessed as the power (level) of the development of his individual and general characteristics.

4. The ratio of the individual and the average group values of individual and general indicators shall allow to assess child's general and special giftedness.

Received 20130910

Approved for publishing 20140214

\section{References}

Бабиева, Н. С. (2008). Эффективность применения теста личностных конструктов для диагностики субъективного смыслового пространства одаренного ребенка. В копилку педагога и психолога, № 4: $103-108$.

Лейтес, Н. С. (2003). О признаках детской одаренности. Вопросы психологии, № 4: 13-18.

Максименко, С. Д. (2006). Генеза здійснення особистості. К., с. 255.

Моляко, В. О. (2008). К вопросу о сущности одаренности. Актуальні проблеми психології: Проблеми психологї обдарованості. Збірник наукових праць. За ред. С. Д. Максименко, Р. О. Семенової, т. 6. Вип. 3. Житомир: Вид-во ЖДУ ім. І., с. 14-22.

Renzulli, J. S. (1986). The three-ring conception of giftedness: A developmental Conceptions of giftedness. New York: Cambridge University Press.

Sternberg, R. J. (2000). Patterns of giftedness: A triarchic analysis. Roeper Review, vol. 22: 231-236. Франка.

Буров, О. Ю., Камишин, В. В. (2008). Оцінювання обдарованості: проблеми кількісної міри. Збірник наукових праць Інституту обдарованої дитини, № 1: 5-9.

Буров, О. Ю., Киричук, В. О., Перцев, М. А. (2010). Внутрішній критерій обдарованості як засіб виявлення обдарованих дітей у системі «Універсал». Матеріали Всеукраїнської науково-практичної конференції «Психолого-педагогічне проектування особистісного розвитку обдарованої дитини в системі навчально-виховного процесу загальноосвітнього навчального закладу», 23-25 березня р., м. Харків. 